\title{
Green Corridors in Urban Landscapes, Case Study Nicosia Pedieos River
}

\author{
By Selda İnançoğlu${ }^{1}$, Özge Özden ${ }^{1 *}$, Can Kara ${ }^{3}$
}

\begin{abstract}
Due to increasing population and expansion of cities, urban planning issues are becoming more important worldwide. It is realized that biological methodologies ought to be coordinated into urban arranging activities. Particularly in European cities, creating greenways and green corridors is a very recent phenomenon. The advancement of green space along urban waterways could moderate urban warmth island impacts, improve the physical and mental prosperity of city occupants, improve flood resilience and could also sustain biodiversity. The Pedieos River is the longest river in Cyprus. Like most of streams on the island, it is a non-enduring waterway, of fleeting nature that for the most part streams during the blustery winter months or after overwhelming precipitation occasions. A literature review was undertaken to discover the importance of rivers within the urbanized areas. It is known that the Pedieos River is firmly connected to the historical backdrop of Nicosia as it is one reason for the city's presence at the site. The increase of impermeable areas as a result of urbanization is also one of the main causes for flooding in recent years. In this research, the current situation of the river was investigated and its possible rehabilitation discussed for more sustainable city. The aim of this study is to recommend a feasible proposition by examining green territory zones and reason green passages along the Pedieos River so as to improve the living condition of Nicosia city.
\end{abstract}

Keywords: Greenway, river, Pedieos River, urban planning

\section{Introduction}

Urban areas consist of diverse semi-natural habitats such as wastelands, parks, streams and other highly human-influenced biotopes. Support of urban biodiversity for the inhabitants and for its basic worth which is looking with expanding populace and extending of urban areas requires high natural information to be incorporated into urban arranging. To achieve this goal, understanding of ecological patterns and processes in urban ecosystems is vital. Niemela (1999) stated that the first step of the necessary urban ecological research is to identify what kind of nature exists within the cities. Second step is to have good knowledge about ecological processes in urban nature. Third, based on ecological knowledge, management schemes maintaining the diversity of urban nature

\footnotetext{
| ${ }^{1}$ Department of Landscape Architecture, Faculty of Architecture, University of Near East, Nicosia, North Cyprus.

${ }^{2}$ Chairperson for the Department of Landscape Architecture, Faculty of Architecture, University of Near

East, Nicosia, North Cyprus. *Corresponding author.

${ }^{3}$ Department of Landscape Architecture, Faculty of Architecture, University of Near East, Nicosia, North Cyprus.
} 
should be designed. These procedures should also include protection of urban nature, e.g. in urban national parks (Niemela, 1999).

As increasing number of individuals live in urban communities, reclamation, preservation and improvement of biodiversity in urban territories become key issue around the world. It is outstanding that enhancement of biodiversity in urban biological systems can have positive effect on the personal satisfaction and instruction of urban residents (Savard et al. 2000). Green areas have been crucial component of city planning over the last century. Green areas can improve climate conditions, aesthetics of the city while they also meet social and psychological needs of urban population (Ignatieva et al. 2011).

The greenways movement in Europe grew uniquely in contrast to in the USA. Europe has seen an intermittent and divided procedure, expanded in the different nations. The blast of the scenic route idea in Europe is an extremely ongoing marvel. The strategy is organized in four stages: investigation of the scene assets, the current green path and authentic course arranges; appraisal of every component; composite evaluation; and meaning of the Greenways Plan. The methodology likewise end up being valuable in the meaning of a system devoted to non-mechanized traffic fit for interfacing the various urban focuses with the numerous assets present in the territory (Fabos, 2003).

The liberal surface spread adjustment of urban territories towards the enormous number of non-evaporative surfaces, for example, cement and black-top, has likewise added to the event of the urban. The advancement of green space along urban waterways could direct urban warmth island impacts, increment the physical and mental prosperity of city inhabitants, and improve flood strength (Ortega et al. 2014).

Green corridors can be characterized as way to deal with give progression of urban green spaces. It helps the connectivity of one habitat fragment to another habitat fragments and this allows an exchange of wildlife members (AlMasri et al. 2019; Curcic and Durdic 2013).It is known that achieving sustainable urban planning by green areas not only helps conservation of nature, it also increase the air quality and also quality of life for urban citizens (Shahani 2012, Rostmai et al. 2013).

This paper points the layout the natural structure which can be created in Nicosia. Greening plan at the territorial, city and neighborhood levels to accomplish long term sustainability could be created for Nicosia city.

\section{Study Area}

The Pedieos River has $100 \mathrm{~km}$ length and it is the longest waterway in Northern Cyprus. Likemost streams on the island; it is a non-enduring waterway, just streams during the blustery winter months or after overwhelming precipitation occasions. It slants from the Troodos mountains at $1400 \mathrm{~m}$ above ocean level and streams towards Nicosia. It moves through the United Nations buffer zone which has been isolating the island since 1974. The riverbed of Pedieos River has a width changing between 5 and 20 $\mathrm{m}$ depending on geomorphologic conditions (Figure 1).

From 1980 to 2010, Pedieos River basin gets a normal yearly precipitation extending between $320 \mathrm{~mm}$ downstream to $670 \mathrm{~mm}$ upstream. It is dammed in the 
upstream region; $20-\mathrm{km}$ outside of the city of Nicosia Downstream from the dam and wetlands, the stream crosses a few rustic networks. The width of the riverbed changes along its direction through the urban area of Nicosia (Charalambous, 2016) (Figure 2). A straight park has been as of late made along the vaporous Pedieos River in the urban region of Nicosia, Cyprus (Giannakis et al. 2016).

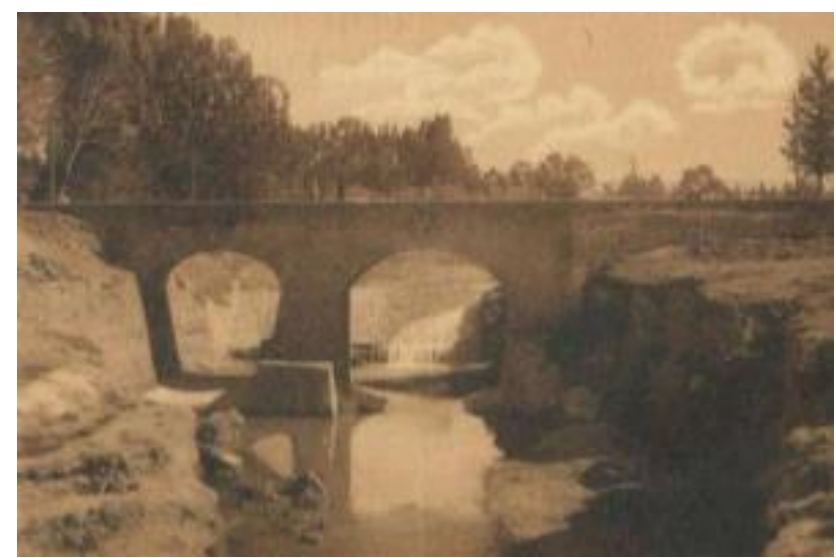

Figure 1: The Pedieos Bridge

Reference: British, 1901 Cyprus Postcard, Avedissian Bros. No. 8: Nicosia River Bridge

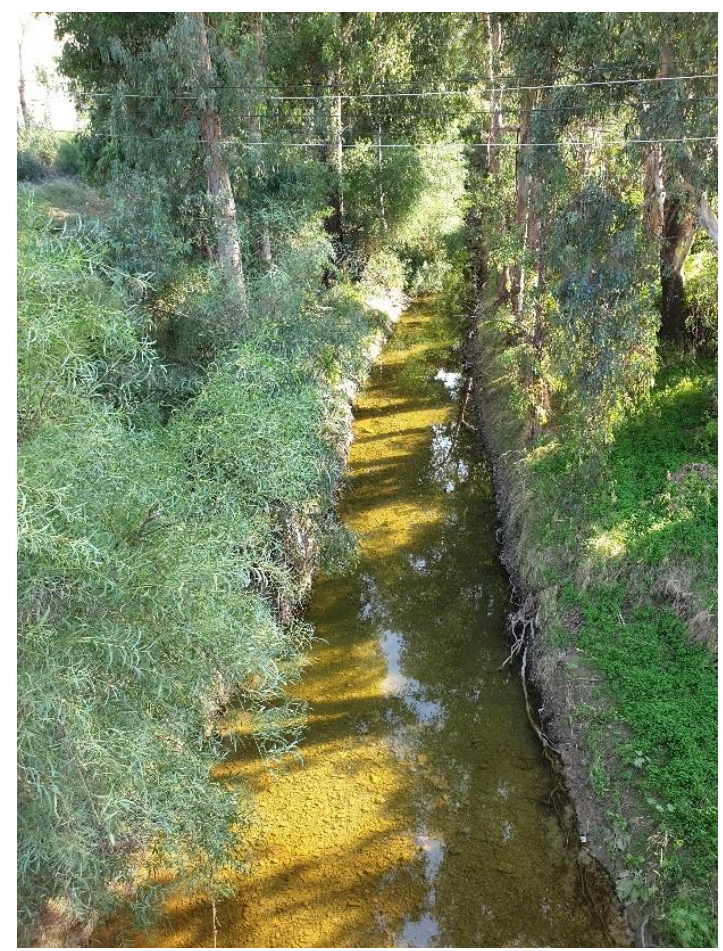

Figure 2: The Pedieos River, 2019 


\section{Material and Methods}

A literature review was undertaken to collect data on the connecting urban and rural areas through green corridor, rivers (Table 1). Additionally, during this study Pedieos River area has been identified on Google Earth map of Nicosia city, and green areas analyzed by overlaying maps that obtained from local offices by using Geographical Information Tools.

Table 1. Summary with basic characteristics of reviewed publications connecting urban and rural areas through green corridor along rivers

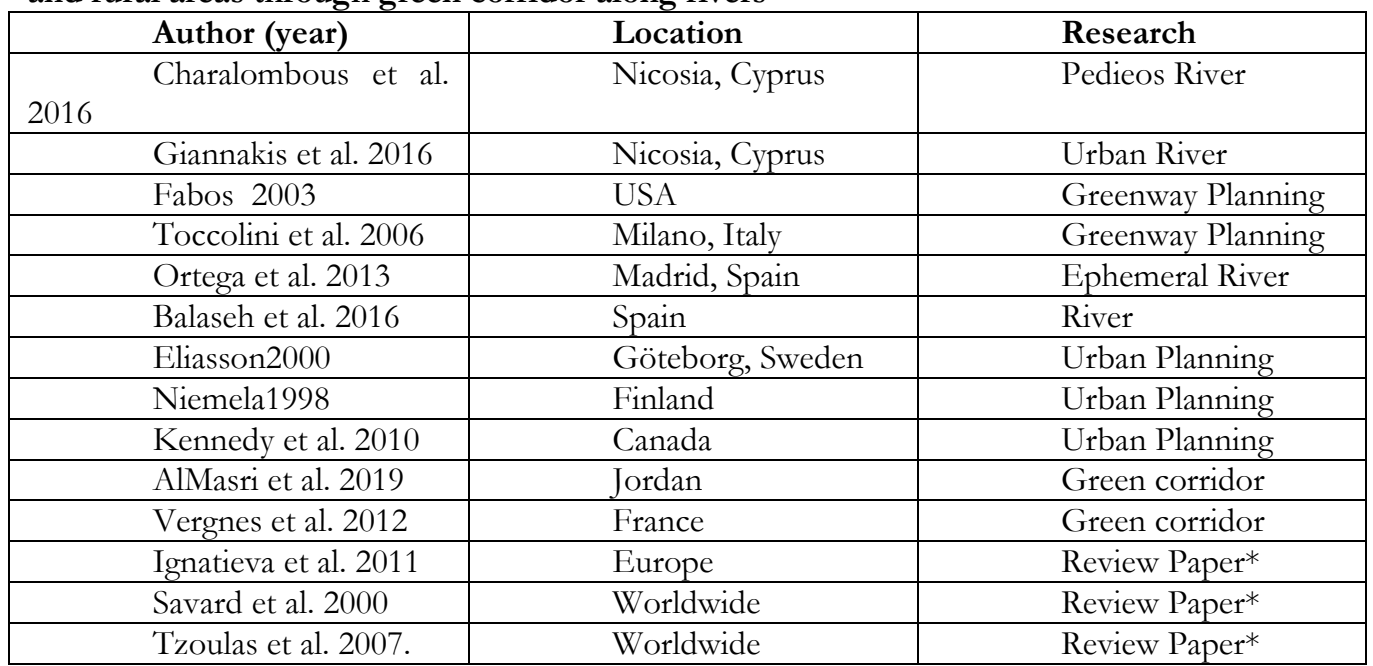

\section{Results and Discussion}

Green areas have been decisive elements of cities and urban planning over the last century. Green area has effect on climate, hygiene, aesthetics, recreational opportunists, environment and biodiversity (Yang et. al. 2005; Sanesi et al. 2006). It is known that urban green areas play a vital role which can be significant part of sustainable development. Urban green areas can range from large parks, urban forests, green fields, street trees, street parks, children parks, private gardens, roof gardens (Kennedy et al., 2010). Recent study on human experience in green environments has been shown that green environment had positive outcomes on humans when they contact with nature (Carrus et al. 2015).

Greenways (green corridors) in cities can connect the patches of green areas between people and the land, also between public parks and historical sites (Toccolini et al., 2006).

Ecological corridors are landscape elements that prevent the negative effects fragmentation. In urban landscapes fragmentation considered as major threat to biodiversity. Unfortunately, loss and degradation of urban and peri-urban green space could unfavorably affect ecosystems as well as human health and well-being.The development of green corridors (intense vegetation) could be an interesting way to limit 
fragmentation and enhance 'biodiversity 'and also in the same time supports sustainable living areas within the cities (Tzoulas et al. 2007; Vergnes et al. 2012). Particularly in the EU member countries, the agenda of design green corridors has been very important issue for planners (Windt and Swart 2008). The green corridors can improve species richness at patch and landscape scales, and this helps maintenance of ecosystems. On the other hand, the availability of green space near your own residence helps to maintain daily physical exercises and this may have positive affect on human health (Lee et al. 2015).

Nicosia Master Plan is a bi-communal on going comprehensive activity, which starts by the 1979. Firstly, NMP proposed to improve infrastructure of Northern and Southern parts of the divided Nicosia after 74. Then Greek and Turkish municipalities of Nicosia have cooperatively worked to improve living conditions of residents of the city. Both Municipalities agreed to improve historical-cultural heritage elements within the walled city and develop central zone by the second phase of the project after 1985. After second phase (1985), NMP concentrated on the revitalizing of the historical core and implemented many urban design projects up to now. Additionally, NMP propose different improvements for the core of the Nicosia for improving public spaces within the city, such as pedestrianization the commercial streets of Ledra and Onasogoru to increase attractiveness and quality of life. Furthermore, Chrysaliniotissa - Arab Ahmet Housing Rehabilitation Programmes also improves of the quality of public open spaces within the city (Ewers 2018).

The Pedieos River is firmly connected to the historical backdrop of Nicosia as it is one reason for the city's presence at the site. The expansion of impermeable zones because of urbanization is additionally one of the fundamental drivers for flooding lately. The absence of comprehensive arranging and nearness of tempest water the board in the city's arranging has all the earmarks of being the significant supporter of flooding issues in the city (Charalambous et al., 2016). During this research, Pedieos River area has been identified on google earth map of Nicosia city, and and green areas analyzed by overlaying maps that obtained from local offices by using Geographical Information Tools. After the analysis of the current green areas along the Pedieos River, possible green corridor area has been proposed for the Nicosia city. The green corridor will be a total 10 meters width within the possible boundaries (5 meters each side of the river) and this will approximately cover a total area of 33.5 ha (Figure 3 and Figure 4). 


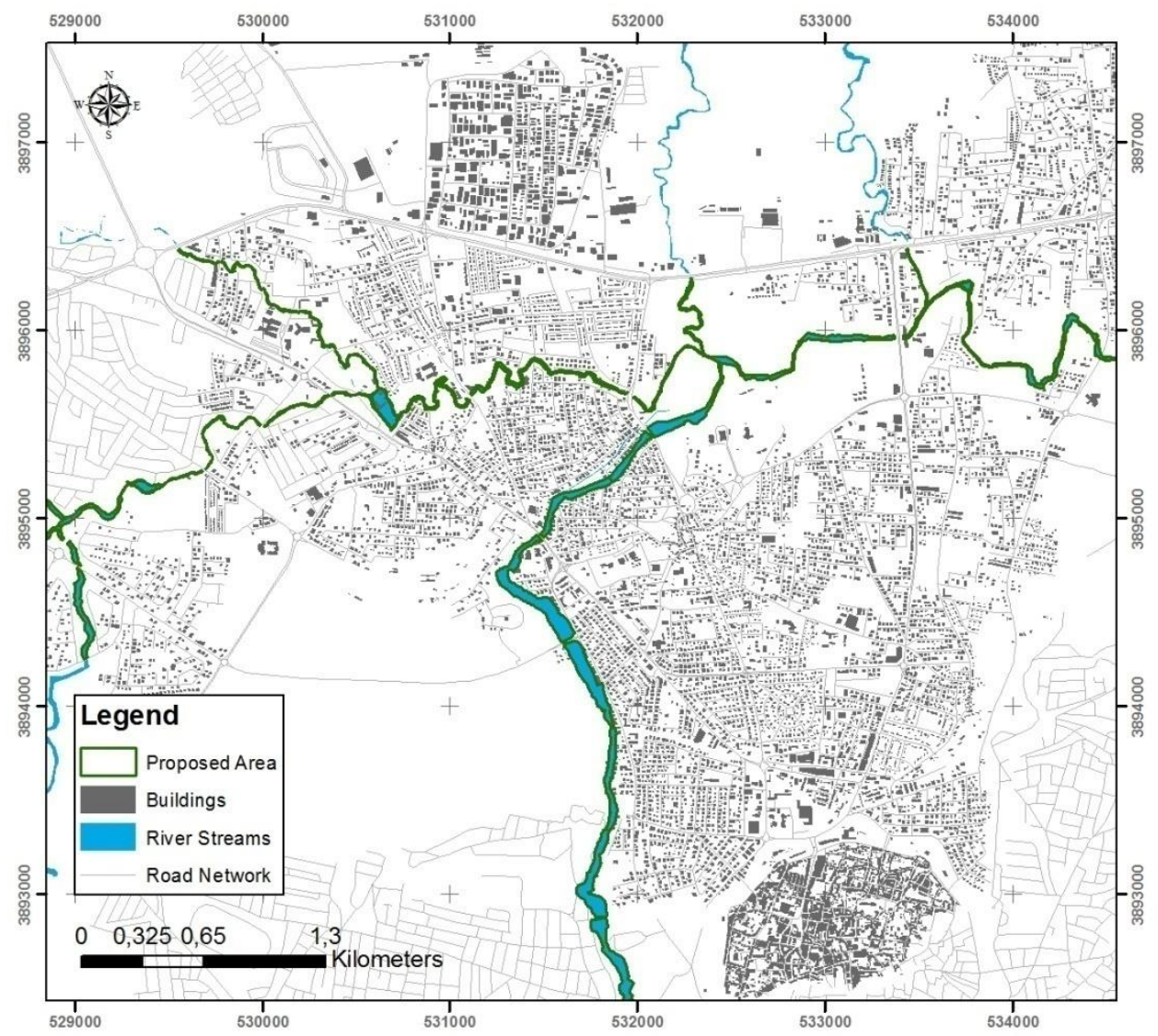

Figure 3: Proposed green corridor development along the Pedieos River 


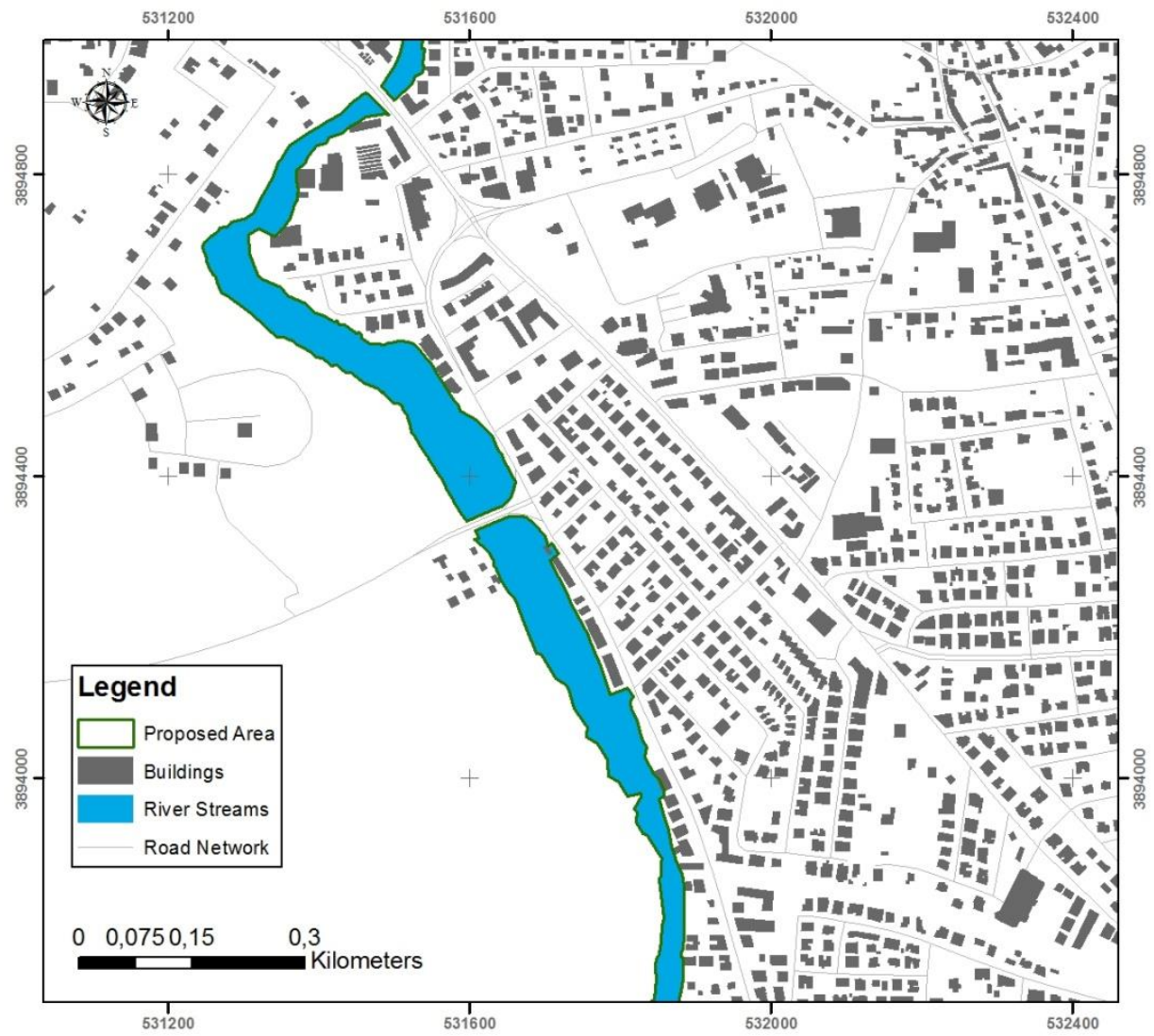

Figure 4: Proposed green corridor development along the Pedieos River

The proposed 'green corridor' along the Pedieos River should be considered as a new approach for the more sustainable living environment for Nicosia city. Proposed green corridor could help creating better urban nature conservation, water management, and landscape quality initiatives within the region. In addition, in order to make this proposal real project, regional and local authorities and stakeholders should be actively involved for the establishment of the "green corridor".

\section{References}

Al Masri A., Özden Ö., Kara C. (2019) Green Corridor Development as an Approach for Environmental Sustainability in Jordan, European Journal of Sustainable Development, 8, 3, 418-438.

British (1901) Cyprus Postcard, Avedissian Bros. No. 8: Nicosia River Bridge

Carrus G., Scopelliti M., Lafortezza R., Colangelo G., Ferrini F., Salbitano F., Agrimi M., Portoghesi L., Semenzato P., Sanesi G. (2015). Go greener, feel better? The positive effects of biodiversity on the well-being of individuals visiting urban and peri-urban green areas. Landscape and Urban Planning, Vol. 134, p.221-228.

Charalombous, K., Bruggeman, A., Bakirtzis, N., Lange, M.A. (2016) Historical Flooding of the Pedieos River in Nicosia, WaterHist, 8: 191-207 
Curcic, N., \&Durdic, S. (2013).The actual relevance of ecological corridors in nature conservation.Journal of The Geographical Institute. 63, 21-34.

Eliasson, I (1999) The Use of Climate Knowledge in Urban Planning, Landscape and Urban Planning, 48: 31-44

Ewers CM. (2018). The Nicosia Master Plan: Historic Preservation as Urban Regeneration, Graduate School of University of Oregon, MSc Thesis, 107 pp.

Fábos, J.G., (2003) Greenway planning in the United States: its origins and recent case studies, Landscape and Urban Planning, 68: 321-342

Giannakis, E., Bruggeman, A., Poulou, D., Zoumides, C. and Eliades, M., (2016) Linear Parks along Urban Rivers: Perceptions of Thermal Comfort and Climate Change Adaptation in Cyprus, Sustainability, $8: 1-16$

Ignatieva M., Stewart GH. And Meurk C. (2011).Planning and Design of Networks in Urban Areas. Landscape Ecol Eng, 7: 17-25.

Kennedy, C., Pincetl, S., Bunje, P. (2010) The Study of Urban Metabolism and its Applications to Urban Planning and Design, Environmental Pollution, 159: 1965-1973.

Lee A.C.K., Jordan H.C. and Horsley J. (2015). Value of Urban Green Spaces in pPromoting Healthy Living and Wellbeing: Prospects for Planning, Risk Manag Health Policy 8: 131-137.

Niemela, J., (1999) Ecology and Urban Planning, Biodiversity and Conservation, 8: 119-131

Ortega, J. A., Razola, L., and Garzón, G., (2013) Recent Human İmpacts and Change in Dynamics and Morphology of Ephemeral Rivers, Madrid, Nat. Hazards Earth Syst. Sci., 14: 713-730

Rostmai, R., Lamit, H., Khoshnava.,\&Rostami, R. (2013). Urban Green Spaces and City Sustainability.Asian Journal of Microbiology, Biotechnology and Environmental Sciences, 15, 441-446.

Sanesi G. Lafortezza R., Bonnes M. Carrus G. (2006). Comparison of two different approaches for assessing the phsychological and social dimensions of green areas.Urban for Urban Green 5: 121-129.

SavardJPL.,Clergeau P. and Mennechez G. (2000). Biodiversity Concepts and Urban Ecosystems, Landscape and Urban Planning, Vol. 48, 131-142.

Shahani, F. (2012).The Role of Green Way in the Achievement of Urban Sustainable Development (District 3 of Tehran as a Case Study).World Applied Sciences Journal, 19, 1514-1522.

Teimouri, R., \&Yigitcanlar, T. (2018). An approach towards effective ecological planning: Quantitative analysis of urban green space characteristics. Global Journal of Environmental Science and Management, 4, 195-206.

Toccolini, A., Fumagalli, N., Senes, G., (2006) Greenways planning in Italy: the Lambro River Valley Greenways System, Milano, Landscape and Urban Planning, 76: 98-111

Tzoulas K., Korpela K., Venn S., Yli-Pelkonen V., Kazmierczak A., Niemela J and James P. (2007). Promoting ecosystem and human health in urban areas using Green Infrastructure: A literature review.Landscape and Urban Planning 81: 167-178.

Windt H.J.V. and Swart J.A.A. (2008). Ecological corridors, connecting science and politics: the case of the Green River in the Netherlands, Journal of Applied Ecology, 45: 124-132.

Vergnes A., Viol I.L., Clergeau P. (2012). Green corridors in urban landscapes affect arthropod communities of domestic gardens. Biological Conservation, 145: 171-178.

Yang J., McBride J., Zhou J., Sun Z. (2005).The urban forest in Beijing and its role in air pollution reduction.Urban for Urban Green 3: 65-78. 